\title{
Raman spectroscopic characterization of a synthetic, non-stoichiometric Cu-Ba uranyl phosphate
}

\author{
Nuria Sánchez-Pastor ${ }^{\mathrm{a}, *}$, André J. Pinto $^{\mathrm{b}}$, José Manuel Astilleros ${ }^{\mathrm{a}, \mathrm{c}}$, Lurdes Fernández-Díaz ${ }^{\mathrm{a}, \mathrm{c}}$, \\ Mário A. Gonçalves ${ }^{b}$
}

\footnotetext{
${ }^{a}$ Department of Crystallography and Mineralogy, Faculty of Geological Sciences, Complutense University of Madrid, C/José Antonio Novais 2, Madrid 28040, Spain

${ }^{\mathrm{b}}$ Department of Geology and CREMINER/LARSys, Faculty of Sciences, University of Lisbon, Ed. C6, 1749-016 Lisbon, Portugal

${ }^{\mathrm{c}}$ Institute of Geosciences (CSIC, UCM), C/José Antonio Novais 2, Madrid 28040, Spain
}

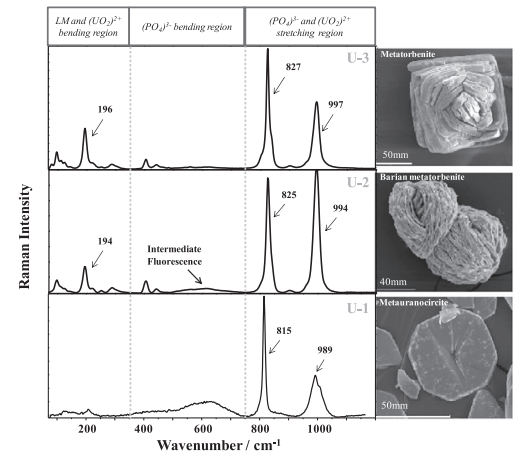

$a b s t r a c t$

Crystals of phases belonging to the autunite group (general formula $\left.\mathrm{X}^{2+}\left(\mathrm{UO}_{2}\right)_{2}\left(\mathrm{X}^{5+} \mathrm{O}_{4}\right)_{2} \cdot \mathrm{nH}_{2} \mathrm{O}\right)$, specifically the uranyl phosphates $\left(\mathrm{X}^{5+}=\mathrm{P}\right)$ metauranocircite $\left(\mathrm{X}^{2+}=\mathrm{B} \mathrm{a}^{2+}\right)$, metatorbernite $\left(\mathrm{X}^{2+}=\mathrm{Cu}^{2+}\right)$ and a barian metatorbenite phase $\left(\mathrm{X}^{2+}=\mathrm{Cu}^{2+} / \mathrm{Ba}^{2+}\right)$, have been synthesized in a silica gel medium and characterized by Raman spectroscopy. The Raman spectra showed bands in the range $750-1100 \mathrm{~cm}^{-1}$, which were attributed to the $\mathrm{m}_{1}$ and $\mathrm{m}_{3}$ ðPO${ }_{4} \mathrm{P}^{3-}$ and $ð \cup \mathrm{O}_{2} \mathrm{p}^{2 \mathrm{p}}$ stretching vibrations. By using the wavenumbers of the most intense and well defined $\mathrm{m}_{1} \succsim \mathrm{UO}_{2} \mathrm{p}^{2 \mathrm{p}}$ vibration, the $\mathrm{U}-\mathrm{O}$ bonds lengths were calculated for the three uranyl phosphate minerals. The results are in good agreement with previous single crystal structure analysis data. Bands in the spectra from 350 to $700 \mathrm{~cm}^{-1}$ were attributed to the $ð \mathrm{PO}_{4} \mathrm{P}^{3-}$ bending modes. Moreover, in the range $70-350 \mathrm{~cm}^{-1}$, two groups of bands could be defined. The first group, with vibra-tions at lower wavenumbers, was attributed to the lattice modes and the second group, from 150 to $350 \mathrm{~cm}^{-1}$, was assigned to the $\mathrm{m}_{2}$ бUO $\mathrm{O}_{2} \mathrm{p}^{2 \mathrm{~b}}$ bending mode. Finally, in the case of the barian metatorbernite, bands in the range $1500-3800 \mathrm{~cm}^{-1}$ were assigned to the $\mathrm{OH}$ stretching and the $\mathrm{m}_{2}$ bending vibrations of water molecules. In this phase, all the vibrations show bandshifts when compared to the vibrations in metatorbernite. These bandshifts can be related to transitional $\mathrm{Cu}-\mathrm{O}$ and $\mathrm{Ba}-\mathrm{O}$ bond lengths.

Keywords: Metatorbernite, Metauranocircite, Raman spectroscopy, Urany, Gel experiments, Phosphates

Introduction

Recently, the study and characterization of the environmental mobility of uranium has known a research increment, following a global reassessment of the nuclear option as a possibly viable energy source [1].

* Corresponding author. Tel.: +34 913944868.

E-mail address: nsanchez@ucm.es (N. Sánchez-Pastor).
The main concerns boosting such increased interest are the storage/disposal-related issues regarding spent nuclear fuel and the need to develop remediation strategies for contaminated sites. Within the outlined framework, uranyl phos-phate-group minerals assume a striking relevance because, due to their extremely low solubility under oxidizing conditions, they 
may ultimately control U-levels in many natural groundwaters [2,3]. In fact, uranium removal from contaminated aqueous fluids by means of insoluble uranyl phosphate phase precipitation - a process triggered within reactive barriers - has been pointed out as offering several technical and economical advantages [4-6]. However, it has been shown that these phases can subsequently alter as they continue to interact with aqueous fluids in natural context. For instance, weathering reactions give rise to important mineralogical relationships with other U-free (e.g. Al, Fe-oxyhy-droxides) and U-bearing phases, a matter still open to discussion [7].

The present study focuses on three uranyl phases belonging to the autunite group $\left(\mathrm{X}^{2+}\left(\mathrm{UO}_{2}\right)_{2}\left(\mathrm{X}^{5+} \mathrm{O}_{4}\right)_{2} \cdot \mathrm{nH}_{2} \mathrm{O}\right.$, where $\mathrm{X}^{2+}$ can be $\mathrm{Ba}$, $\mathrm{Cu}$, or $\mathrm{Mg}$, and $\left.\mathrm{X}^{5+}=\mathrm{P}, \mathrm{As}\right)$, specifically the uranyl-phosphate $\left(\mathrm{X}^{5+}=\right.$ P) phases metatorbernite $\left(X^{2+}=\mathrm{Cu}^{2+}\right)$, metauranocircite $\left(\mathrm{X}^{2+}=\mathrm{B} \mathrm{a}^{2}\right.$ ${ }^{+}$) and a barian metatorbernite $\left(\mathrm{X}^{2+}=\mathrm{Cu}^{2+} / \mathrm{Ba}^{2+}\right)$. Autunite group basic structure can be briefly described as parallel sheets of $\left.1 / 2 \mathrm{UO}_{2} \mathrm{PO}_{4}\right]_{n}^{\mathrm{n}}{ }_{\mathrm{n}}^{-}$with a hydrated interlayer containing both indepen-dent $\mathrm{H}_{2} \mathrm{O}$ groups and water-coordinated and divalent cations. In a structural classification based on the anion sheet topology, autunite group configurations reflect square-bearing topologies, even though important differences may be found between meta-torbernite and metauranocircite [8]. For instance, the $\left.1 / 2 \mathrm{UO}_{2} \mathrm{PO}_{4}\right]_{n}^{n-}$ metatorbernite sheets are "undistorted", while in metauranocircite they present considerable deviations from the ideal autunite-type sheet [9]. Moreover, significant contrasts can also be encountered between the interlayers of both structures, affecting the geometry of cation coordination polyhedron, independent $\mathrm{H}_{2} \mathrm{O}$ groups and sheet-tointerlayer bonding. An extensive review of the structural characteristics of uranium-bearing crystalline structures is included in Burns [9].

Here, we study the crystallization of $\mathrm{Cu}$ and $\mathrm{Ba}$ phases belong-ing to the autunite-group using the double diffusion variant of the silica hydrogel method [10,11]. Such technique is most suitable for specifically emulating natural media where crystals grow from confined aqueous solutions and under limited mass transfer conditions [12,13] - e.g. sediments and soils [14]. The experimental growth of uranyl phosphates in nanoporous hydrogel has been per-formed in the past [15], but no references exist with respect to gel-grown phases incorporating $\mathrm{Ba}$ and $\mathrm{Cu}$, in spite of reported natural occurrences $[7,16,17]$.

When the approached phases are present in scarce amounts and the experimental methods to synthesize them involve prolonged reaction times, sensitive characterization techniques assume utter importance, while in other contexts the information provided may be merely complementary. Here, we introduce a study performed in hard-to-grow synthetic uranyl phosphates, where sample size and amount were constant limiting factors during analytical stages. In this research, we performed micro-Raman analysis on the synthetic samples grown in the hydrogel, paying special atten-tion to the samples incorporating both $\mathrm{Ba}$ and $\mathrm{Cu}$. This allowed us to characterize the barian metatorbernite following the crucial studies by Frost group [18-20] and the infrared reference informa-tion by Cejka et al. [21].

\section{Experimental}

Crystal growth: gel experiments

The crystallization experiments were performed in a double diffusion system consisting of two vertical branches separated by a horizontal column of inert silica hydrogel, as shown in Fig. 1. The vertical branches were filled with $\mathrm{UO}_{2}\left(\mathrm{NO}_{3}\right)_{2} \cdot 6 \mathrm{H}_{2} \mathrm{O}+\mathrm{BaCl}_{2}+$ $\mathrm{Cu}\left(\mathrm{NO}_{3}\right)_{2}$ and $\mathrm{H}_{3} \mathrm{PO}_{4}$ aqueous solutions, according to the reactant combinations and concentrations displayed in Table 1. The silica hydrogel column was $125 \mathrm{~mm}$ long and $9 \mathrm{~mm}$ in diameter. The gel was prepared by adding $1 \mathrm{~N} \mathrm{HCl}$ to a sodium silicate solution $\left(\mathrm{Na}_{2} \mathrm{SiO}_{3}\right)\left(\right.$ Merck KGaA, sp. gr.: $\left.1.509 \mathrm{~g} / \mathrm{cm}^{3} ; \mathrm{pH}=11.2\right)$ until $\mathrm{pH}=$ 5.5 was reached. The reactants are brought together by diffu-sion through the gel nanoporous media and, subsequently, nucle-ation and crystal growth occurred by chemical reaction within the gel column. Crystal growth was monitored by optical micros-copy. Two months after nucleation, the experiments were stopped and the crystals were extracted by dissolving the gel in a $1 \mathrm{M} \mathrm{NaOH}$ solution. Finally, the obtained individuals were left to dry at room temperature. All experiments were carried out at $25 \square$ C.

\section{Morphological and structural characterization of the crystals}

Crystals with representative morphologies were hand-picked, checked under optical stereo microscope and studied using a scan-

Table 1

Concentrations of reactants used in double-diffusion experimental settings.

\begin{tabular}{lllll}
\hline \multicolumn{4}{l}{ Experiment $\mathrm{UO}_{2}\left(\mathrm{NO}_{3}\right)_{2} \cdot 6 \mathrm{H}_{2} \mathrm{O}(\mathrm{M}) \mathrm{BaCl}_{2}(\mathrm{M}) \mathrm{Cu}\left(\mathrm{NO}_{3}\right)_{2}(\mathrm{M}) \mathrm{H}_{3} \mathrm{PO}_{4}(\mathrm{M})$} \\
\hline $\mathrm{U}-1$ & 0.01 & 0.05 & - & 0.1 \\
$\mathrm{U}-2$ & 0.01 & 0.25 & 0.05 & 0.25 \\
$\mathrm{U}-3$ & 0.01 & - & 0.1 & 0.25 \\
\hline
\end{tabular}

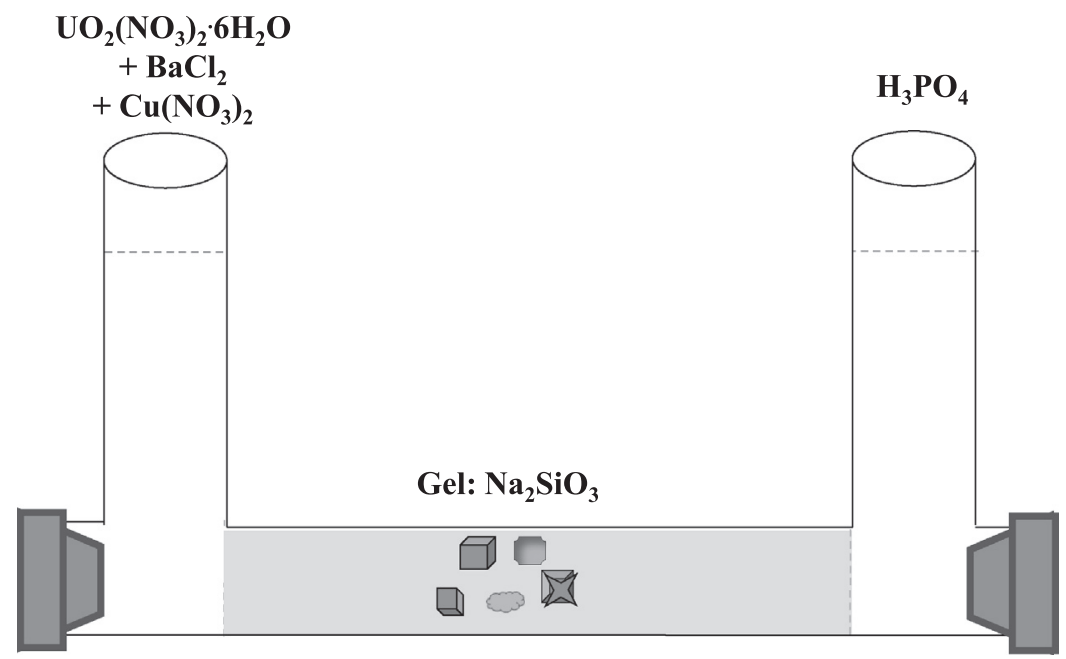

Fig. 1. Schematic representation of the experimental device applied to nucleate and grow the approached uranyl phosphate phases. 
ning electron microscope (JEOL JSM6400, $40 \mathrm{kV}$ ), equipped with a LINK Ex1 energy dispersive spectrometer.

Raman spectra of the samples were collected using a confocal Thermo Fischer DXR Raman Microscope, which has point-and-shoot Raman capability of one micron spatial resolution. The objec-tive selected was of $10 \times$ magnification together with a laser source 532 $\mathrm{nm}$ at $10 \mathrm{~mW}$ in a laser mode power at $100 \%$. The average spec-tral resolution of the Raman shift ranging from 70 to $3400 \mathrm{~cm}^{-1}$ was 2-4 $\mathrm{cm}^{-1}$, i.e., grating 900 lines $/ \mathrm{mm}$ and a spot size of $2 \mathrm{~lm}$. The system was operated under OMNIC 1.0 software fitting working conditions such as pinhole aperture of $25 \mathrm{~lm}$ and bleaching time of 1-2 s; four exposures averaged in time of $12 \mathrm{~s}$ each.

Band component analysis was carried out using the software package "Fityk" [22], which enables to analyze data from Raman spectroscopy selecting different functions. Moreover, the software allows fixing or varying specific parameters such as the height, the center and the hwhm (half width at half maximum) of the bands.

\section{Results and discussion}

\section{Chemical and morphological characterization of the samples}

Fig. 2a and $b$ displays SEM micrographs of crystals grown in experiments $\mathrm{U}-1$ and $\mathrm{U}-3$, respectively, with spectra from representative semi-quantitative point EDX microanalyses also included. These analyses were performed on the most developed surfaces, which offered the best orientation for analytical purposes. Semi-quantitative EDX point analyses of the crystals obtained in the experiment U-1 (Fig. 2a) revealed a Ba-bearing composition with equal molar amounts of uranium and phosphorus. This chem-ical information is consistent with the composition of metaurano-circite, $\mathrm{Ba}\left(\mathrm{UO}_{2}\right)_{2}\left(\mathrm{PO}_{4}\right)_{2} \cdot \mathrm{nH}_{2} \mathrm{O}$. It has been shown that hydration states of $\mathrm{nH}_{2} \mathrm{O}=12$ and 10 correspond to very unstable hemihy-drates under atmospheric vapor pressure, rapidly changing to $\mathrm{nH}_{2} \mathrm{O}=8 \quad[23,24]$. Likewise, $\mathrm{nH}_{2} \mathrm{O}=6$ hydration is only achieved at high temperatures $[25,26]$, outside the range applied in the pres-ent study. Thus, it is highly unlikely that the gel-grown metaurano-circite corresponds to other type than the $\mathrm{nH}_{2} \mathrm{O}=8$ hemihydrate. These crystals are bounded by the $\left\{\begin{array}{lll}0 & 0 & 1\end{array}\right\}$ dominant pinacoid and lateral faces that could be ascribed to two $\left\{\begin{array}{ll}1 & 00\end{array}\right\}$ and $\left\{\begin{array}{ll}11 & 0\end{array}\right\}$ pseudotetragonal prisms, reflecting an apparent $4 / \mathrm{m} 2 / \mathrm{m} 2 / \mathrm{m}$ tetragonal symmetry. In fact, such external morphological configuration has been acknowledged in some uranyl phosphates [16,27]. In spite of crystallizing with monoclinic structure, structural determinations performed in different hydrates of metauranocircite yielded very similar dimensions for both $a$ and $b$ axis, as well $a s b$ angles very close to $90 \square[26,28]$. Thus, it is not surprising that the external shapes of metauranocircite individuals may be de-scribed as reflecting pseudo-tetragonal symmetry. Moreover, there exists some evidence in the literature reporting the possibility of a "tetragonal" metauranocircite, sharing a similar hydration state to metatorbernite $[6,7]$.

The EDX analyses of the crystals obtained in experiments U-3 (Fig. 2b) indicate that they correspond to a copper-uranyl-phos-phate compound, also with $1: 1 \mathrm{U}: \mathrm{P}$ content. This $\mathrm{U}: \mathrm{P}$ ratio is typi-cal of $\mathrm{Cu}\left(\mathrm{UO}_{2}\right)_{2}\left(\mathrm{PO}_{4}\right)_{2} \cdot \mathrm{nH}_{2} \mathrm{O}$ minerals included in the autunite-group $[15,16]$. These analysis point to metatorbernite since the hydration state $\mathrm{nH}_{2} \mathrm{O}=8$ is the most stable under the induced experimental conditions and metatorbernite has been demon-strated hard to either dehydrate or rehydrate at room temperature $[29,30]$. The morphology of the aggregate depicted in Fig. $2 b$ can be briefly described as tabular-shaped crystals, intergrown in rosette-like aggregates. A closer look reveals poorly defined lateral faces, whose intersection with the most developed surface forms equally-lengthened edges at right angles from each other. Such morphological features are consistent with the habit commonly exhibited by metatorbernite crystals, which belong to the $4 / \mathrm{m}$ point group. This habit is dominated by the $\left\{\begin{array}{lll}0 & 0 & 1\end{array}\right\}$ pinacoid, and two tetragonal prisms, most probably $\{10$ $0\}$ or $\{110\}$.

Fig. $2 c$ shows an aggregate obtained in the experiment U-2. The EDX analyses of the crystals obtained in this experiment yield very similar results to those corresponding to the crystals obtained in experiment U3 and are, therefore, consistent with a Cu-uranyl phosphate. However, as can be seen in Fig. 2c, in this case Ba has also been detected, being the average content $\mathrm{Cu}=94 \%$ and $\mathrm{Ba}=6 \%$ apfu. Although no significant chemical differences have been detected be-tween different crystals obtained in experiment U2, they show a variety of morphologies, ranging from rosette-like aggregates very similar to those obtained in experiment U2 (see Fig. $2 b$ ) to aggre-gates with a marked misorientation of layers stacked along [0 0 1]. An example of the latter morphology is shown in the enhanced image on the upper right corner of Fig. $2 \mathrm{c}$, where the occurrence of cleavage fractures subparallel to individual edges can be clearly
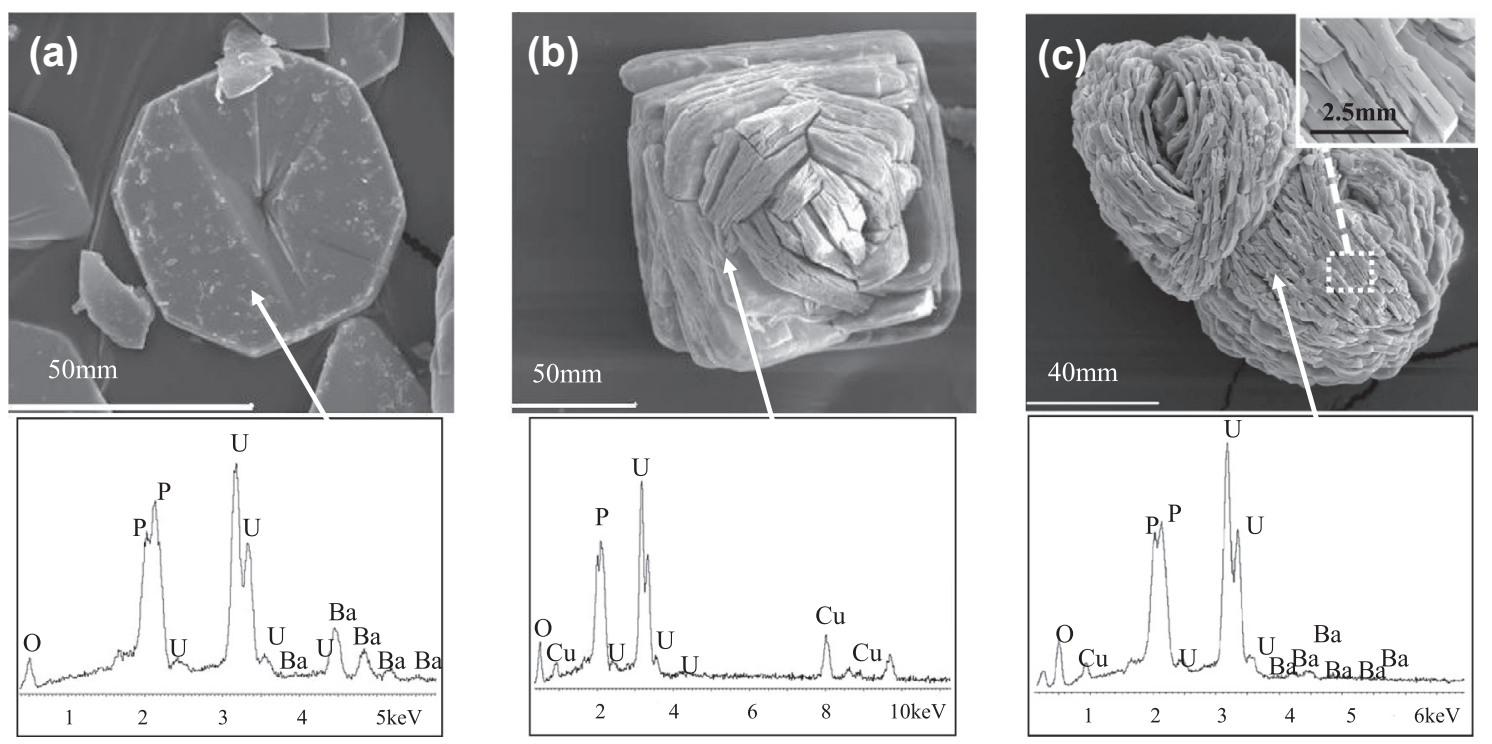

Fig. 2. SEM micrographs and representative EDX analyses of (a) crystal individual grown in experiment U-1, (b) rosette crystal aggregate grown in experiment U-3 and (c) spherical aggregates of a $\mathrm{Cu}^{2+} / \mathrm{Ba}^{2+}$ uranyl phosphate. 
observed. The variety of morphologies observed in this case is interpreted to result from the progressive development of split growth phenomena. The incorporation of barium into the structure of metatorbernite during growth disrupts the normal growth pattern and triggers the development of split growth.

\section{Raman spectroscopy}

The Raman spectra of metauranocircite (U-1), barian metatorbernite (U-2) and metatorbernite (U-3) can be observed in Fig. 3 in the $70-1200 \mathrm{~cm}^{-1}$ range. The spectrum of metauranocircite U1 , especially when compared to the other two spectra of the $\mathrm{Cu}$ bearing phases, is broad due to the effect of fluorescence and the identification of the overlapped bands was difficult in some areas of the spectrum. However, the quenching ability of copper on fluorescence in the metatorbenite gives better defined peaks where the band fitting analysis was quite reliable. The intermediate fluorescence obtained for the barian metatorbernite (U-2) can be observed in Fig. 3. The spectra are divided into three different areas that will be discussed separately in the following sections. The area between 750 and $1100 \mathrm{~cm}^{-1}$ corresponds to the region in which the symmetric and the antisymmetric stretching vibrations of phosphate $\left(\mathrm{PO}_{4}\right)^{3-}$ and uranyl $\left(\mathrm{UO}_{2}\right)^{2+}$ groups can be seen. The attribution of the bands present in the region $350-750 \mathrm{~cm}^{-1}$ is for the symmetric and antisymmetric bending vibrations of $\left(\mathrm{PO}_{4}\right)^{3-}$. The following region, from 150 to $300 \mathrm{~cm}^{-1}$, shows bands assigned to the $\left(\mathrm{UO}_{2}\right)^{2+}$ symmetric bending modes. The lattice modes (LM) can be observed from 70 to $150 \mathrm{~cm}^{-1}$. The results of the band component analysis are reported in Table 2 .

The presence of water in the uranyl mica structure is very important for the stability of the autunite layered structure minerals [20]. In the spectra, in the $1400-1650 \mathrm{~cm}^{-1}$ region, the possible vibrations of the $\mathrm{HOH}$ bending modes of water and the bands related to the $\mathrm{U}-\mathrm{OH}$ deformation appear. The data obtained in the fitting process are included in Table 2. Furthermore, in the case

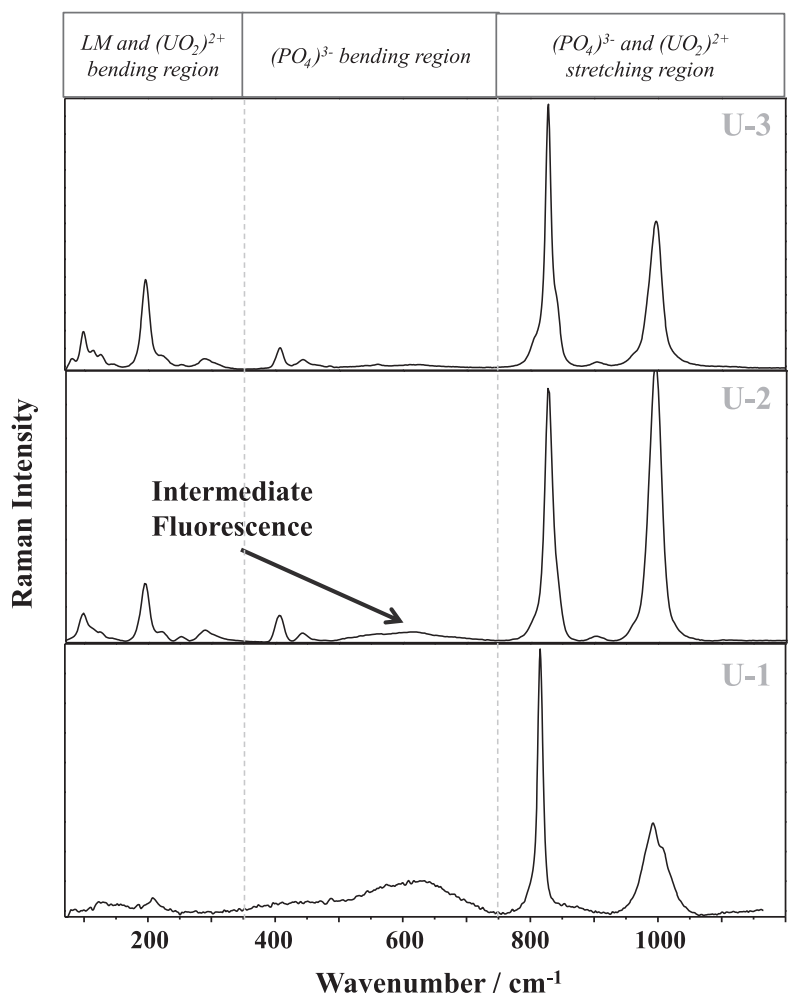

Fig. 3. Raman spectra of the $U-1, U-2$ and $U-3$ samples in the $70-1200 \mathrm{~cm}^{-1}$ region. of the $\mathrm{U}-2$ sample, the analysis of the $\mathrm{OH}$ stretching region of the water molecules $\left(2600-3800 \mathrm{~cm}^{-1}\right)$ was also possible.

$\left(\mathrm{PO}_{4}\right)^{3-}$ and $\left(\mathrm{UO}_{2}\right)^{2+}$ stretching region

The Raman spectra of the three uranium solids in the 750$1100 \mathrm{~cm}^{-1}$ region are shown in Fig. 4 . The band component analysis of the region around $1000 \mathrm{~cm}^{-1}$ display some difficulties due to the overlap of bands associated with the stretching vibrations of the $\left(\mathrm{PO}_{4}\right)^{3-}$ and $\left(\mathrm{UO}_{2}\right)^{2+}$ units. The Raman spectrum of metauranocircite (U-1) shows a set of medium intensity bands at 1039, 1023, 1003, 989 and $960 \mathrm{~cm}^{-1}$. It has been reported that the $\left(\mathrm{PO}_{4}\right)^{3-}$ bands attributed to the symmetric stretching mode $\left(v_{1}\right)$ in Ba-uranyl phosphate minerals can appear at $964,971,991,995 \mathrm{~cm}^{-1}$ and the antisymmetric stretching mode $\left(v_{3}\right)$ at 1006, 1046 and $1059 \mathrm{~cm}^{-1}[18,20,31]$. Thus, the first three bands at 1039, 1023 and $1003 \mathrm{~cm}^{-1}$ can be attributed to the $\left(\mathrm{PO}_{4}\right)^{3-}$ antisymmetric stretching vibrations and the other two bands at 989 and $960 \mathrm{~cm}^{-1}$ are assigned to the symmetric stretching vibrations of the same unit. In the case of metatorbernite (U-3), only three bands are present in this region at 1014,997 and $986 \mathrm{~cm}^{-1}$. In the literature [18], bands at 988 and $996 \mathrm{~cm}^{-1}$ are assigned to the symmetric stretching vibrations of the $\left(\mathrm{PO}_{4}\right)^{3-}$ units in metatorbernite and are in good agreement with our results. The band at $1014 \mathrm{~cm}^{-1}$ is assigned to the antisymmetric stretching mode of phosphate. Finally, the sample U-2, which is interpreted as a barian metatorbernite, shows bands clearly closer to those reported here U-3. The intense band at $994 \mathrm{~cm}^{-1}$ is assigned to the symmetric stretching mode of phosphate together with a low intensity shoulder at $963 \mathrm{~cm}^{-1}$. The bands at 1006 and $1050 \mathrm{~cm}^{-1}$ belong to the $\left(\mathrm{PO}_{4}\right)^{3-}$ antisymmetric stretching vibrations. In all the cases, two bands were assigned to the $\left(\mathrm{PO}_{4}\right)^{3-}$ symmetric stretching vibration indicating the presence of the two non-equivalent phosphate units in the minerals belonging to the autunite group.

The most intense band of the U- 1 and U-3 spectra can be observed in the $\left(\mathrm{UO}_{2}\right)^{2+}$ stretching region at 815 and $827 \mathrm{~cm}^{-1}$, respectively. For $U-2$, the band at $825 \mathrm{~cm}^{-1}$ is the second in intensity. In the three spectra, two shoulders on both sides of the intense band can be seen (Fig. 4 and Table 1). For all the vibrations seen in this region, an increase of the vibrational frequencies with the content in copper is depicted. An analogous phenomenon with bandshifts moving to lower wavenumbers was reported by various authors [32,33]. The $\mathrm{Cu}-\mathrm{O}$ bond-length is shorter and its bonding strength is higher than that of $\mathrm{Ba}-\mathrm{O}$, i.e. the ionic radius of $\mathrm{Ba}^{2+}$ is larger $(1.35 \AA)$ than that of $\mathrm{Cu}^{2+}(0.69 \AA)$. Moreover, the structures of metatorbernite and metauranocircite contain their divalent cations in the interlayers, where $\mathrm{H}_{2} \mathrm{O}$ groups transmit bond valence between structural units, and between the later and interstitial cations, via $\mathrm{H}$ bonds [9]. Thus, in spite of involving different coordination polyhedra, barium may replace for copper within the interlayer of the metatorbernite structure. Such substitution is governed mostly by bond-valence requirements in cation-exchange reactions, giving rise to non-stoichiometric compositions.

Finally, in the $\left(\mathrm{PO}_{4}\right)^{3-}$ and $\left(\mathrm{UO}_{2}\right)^{2+}$ stretching region, a low intensity band is found at around $900 \mathrm{~cm}^{-1}$ in nearly all the Raman spectra of the uranyl micas [18]. In our spectra these bands are broad and poorly defined and are present at 902 and $905 \mathrm{~cm}^{-1}$ for U-2 and U-3, respectively. The position of these bands is in agreement with the $\left(\mathrm{UO}_{2}\right)^{2+}$ antisymmetric stretching modes $\left(v_{3}\right)$.

An empirical approach to assess $\mathrm{U}-\mathrm{O}_{\mathrm{Ur}}$ atomic distances in single uranyl groups, has been proposed by Bartley and Cooney [34], using $\left(\mathrm{UO}_{2}\right)^{2+} v_{1}$ and $v_{3}$ band intensities, according to the following relationships:

$\mathrm{R}_{\mathrm{U}-\mathrm{O}}=106.5\left[v_{1}\left(\mathrm{UO}_{2}\right)^{2+}\right]^{-2 / 3}+0.575 A^{\circ}$

$\mathrm{R}_{\mathrm{U}-\mathrm{O}}=91.42\left[v_{3}\left(\mathrm{UO}_{2}\right)^{2+}\right]^{-2 / 3}+0.804 A^{\circ}$ 
Table 2

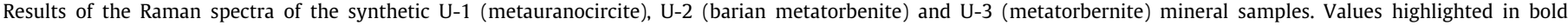
correspond to the highest intensity in each region.

\begin{tabular}{|c|c|c|c|}
\hline U-1 & $\mathrm{U}-2$ & U-3 & Band assignments \\
\hline- & $\begin{array}{l}3476 \\
\mathbf{3 3 6 0} \\
3212 \\
3040\end{array}$ & - & $v \mathrm{OH}$ stretching vibrations of water molecules \\
\hline $\begin{array}{l}1420 \\
1543\end{array}$ & $\begin{array}{l}1412 \\
1536\end{array}$ & $\begin{array}{l}1414 \\
1514\end{array}$ & $v 2(\delta) \mathrm{H}_{2} \mathrm{O}$ bending vibrations \\
\hline 1635 & 1635 & 1630 & $\mathrm{~d}$ U-OH deformation \\
\hline $\begin{array}{l}1039 \\
1023 \\
1003\end{array}$ & $\begin{array}{l}1050 \\
1006\end{array}$ & 1014 & $v_{3}\left(\mathrm{PO}_{4}\right)^{3-}$ antisymmetric stretching vibrations \\
\hline $\begin{array}{l}989 \\
960\end{array}$ & $\begin{array}{l}994 \\
963\end{array}$ & $\begin{array}{l}997 \\
986\end{array}$ & $v_{1}\left(\mathrm{PO}_{4}\right)^{3-}$ symmetric stretching vibrations \\
\hline- & 902 & 905 & $v_{3}\left(\mathrm{UO}_{2}\right)^{2+}$ antisymmetric stretching vibrations \\
\hline $\begin{array}{l}821 \\
815 \\
809\end{array}$ & $\begin{array}{l}831 \\
825 \\
809\end{array}$ & $\begin{array}{l}831 \\
827 \\
806\end{array}$ & $v_{1}\left(\mathrm{UO}_{2}\right)^{2+}$ symmetric stretching vibrations \\
\hline $\begin{array}{l}627 \\
566 \\
502\end{array}$ & $\begin{array}{l}612 \\
547 \\
512\end{array}$ & $\begin{array}{l}627 \\
602 \\
560 \\
541\end{array}$ & $v_{4}\left(\mathrm{PO}_{4}\right)^{3-}$ antisymmetric bending vibrations \\
\hline $\begin{array}{l}425 \\
409 \\
398 \\
376\end{array}$ & $\begin{array}{l}470 \\
460 \\
440 \\
421 \\
\mathbf{4 0 4} \\
384\end{array}$ & $\begin{array}{l}464 \\
443 \\
429 \\
412 \\
406 \\
399\end{array}$ & $v_{2}\left(\mathrm{PO}_{4}\right)^{3-}$ symmetric bending vibrations \\
\hline 222 & $\begin{array}{l}301 \\
286 \\
251 \\
222 \\
208 \\
\mathbf{1 9 4} \\
174\end{array}$ & $\begin{array}{l}291 \\
253 \\
221 \\
196\end{array}$ & $v_{2}\left(\mathrm{UO}_{2}\right)^{2+}$ symmetric bending vibrations \\
\hline- & $\begin{array}{r}142 \\
126 \\
104 \\
\mathbf{9 6}\end{array}$ & $\begin{array}{r}145 \\
125 \\
113 \\
\mathbf{9 9} \\
81\end{array}$ & Lattice modes \\
\hline
\end{tabular}

where $\mathrm{R}_{\mathrm{U}-\mathrm{O}}$ corresponds to a specific $\mathrm{U}-\mathrm{O}_{\mathrm{Ur}}$ atomic distance in $\AA$. Both metauranocircite and metatorbernite include two non-equivalent uranyl groups in their structure, each involving pairs of U-O links of unequal dimensions. Nevertheless, the relationships proposed by Bartley and Cooney [34] can offer further insight with respect to structural variations as a function of divalent cation composition, even though not all U-O distances can be determined for the present case. Thus, Table 3 displays $\mathrm{U}-\mathrm{O}_{\mathrm{Ur}}$ bond lengths calculated according to the expression (1), since $v_{3}$ band intensities offered less reliable information, due to excessive peak broadening, in spite of a rough agreement with reference data [18]. Values highlighted in bold correspond to the highest intensity $v_{1}\left(\mathrm{UO}_{2}\right)^{2+}$ bands, resulting in the most accurate sources for determining $\mathrm{U}-\mathrm{O}$ bond lengths. Atomic U-O distances calculated for both Ba and Cu-bearing phases match exactly the values reported from X-ray single crystal determinations for $\mathrm{U}(2)-\mathrm{O}(4)$ [26] and $\mathrm{U}(2)-\mathrm{O}(3)$ [15] links respectively. In spite of inexistent references concerning $\mathrm{Ba}-\mathrm{Cu}$ compositions, the value obtained for a comparable U-O link in the barian metatorbernite stands in between those calculated for metatorbernite and metauranocircite, a trend already found in the present study for other spectroscopic parameters.

$\left(\mathrm{PO}_{4}\right)^{3-}$ bending region

The bending modes $\left(v_{2}\right)$ and $\left(v_{4}\right)$ are observed in the region $350-700 \mathrm{~cm}^{-1}$. The Raman spectra of $\mathrm{U}-1, \mathrm{U}-2$ and $\mathrm{U}-3$ in this region are reported in Fig. 5. As can be seen, two band associations can be separated. The first group at approximately $400 \mathrm{~cm}^{-1}$ shows the bands belonging to the $v_{2}\left(\mathrm{PO}_{4}\right)^{3-}$ symmetric bending vibrations and, around $600 \mathrm{~cm}^{-1}$, the second group of broad and poor defined bands related to the $v_{4}\left(\mathrm{PO}_{4}\right)^{3-}$ antisymmetric bending modes can be seen. The $v_{2}$ modes show the most intense bands at 398 and $409 \mathrm{~cm}^{-1}$ for U-1, at 402 and $440 \mathrm{~cm}^{-1}$ for U-2 and at 406 and $443 \mathrm{~cm}^{-1}$ for U-3. The assignment of the U-3 bands to the $v_{2}$ metatorbernite modes is in agreement with the previous study from Frost [18]. In the case of the U-1, the bandshifts to lower wavenumbers $\left(376,398,409\right.$ and $\left.425 \mathrm{~cm}^{-1}\right)$ can be explained, as in the case of the $\left(\mathrm{PO}_{4}\right)^{3-}$ and $\left(\mathrm{UO}_{2}\right)^{2+}$ stretching modes, by the larger $\mathrm{Ba}-\mathrm{O}$ bond-length and the related lower bonding strength. The sample U-2 shows values very similar to those of metatorbernite $\left(384,404,521,440,460\right.$, and $470 \mathrm{~cm}^{-1}$; Table 2) with light shifts to lower wavenumbers which may be probably due to the distortion caused by the entrance of $\mathrm{Ba}$ in the hydrated layer.

Lattice modes and $v_{2}\left(\mathrm{UO}_{2}\right)^{2+}$ bending region

The broad spectral profile reflected in the Raman spectrum of $U$ 1 in the $70-350 \mathrm{~cm}^{-1}$ region made the assignment of the bands quite complicated and the interpretation could only be made in terms of the samples U-2 and U-3. The Raman spectra of this region are shown in Fig. 6. It is clear that the spectra can be subdivided into two spectral regions, namely $70-150 \mathrm{~cm}^{-1}$ and $150-350 \mathrm{~cm}^{-1}$. The 


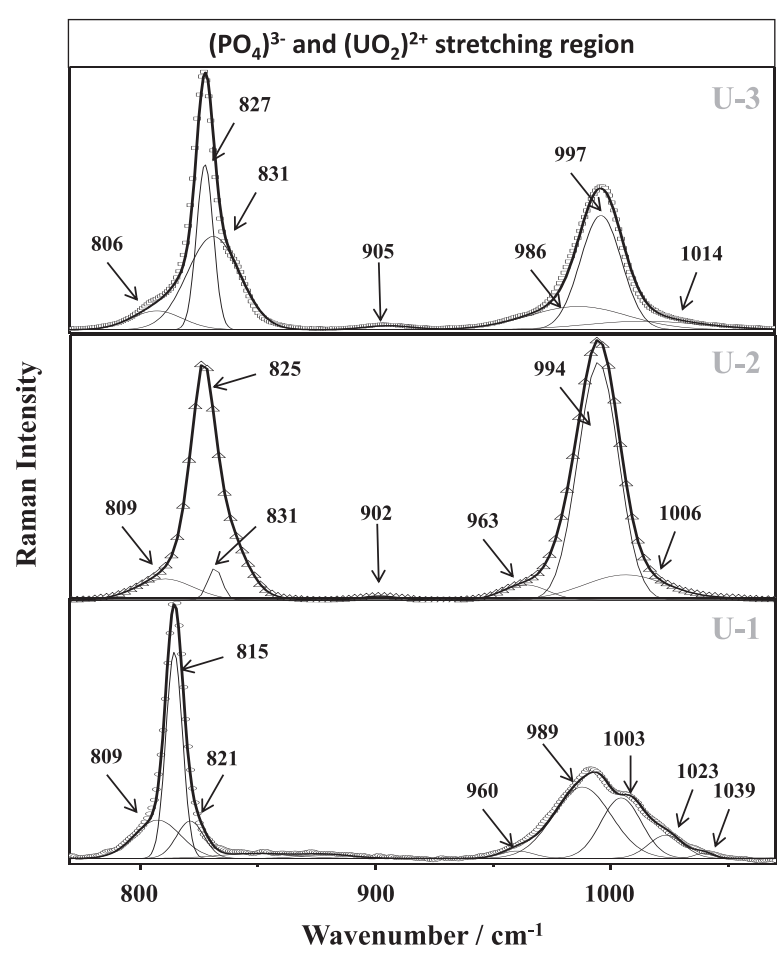

Fig. 4. Raman spectra of the $U-1, U-2$ and $U-3$ samples in the phosphate and uranyl stretching region $\left(700-1200 \mathrm{~cm}^{-1}\right)$

Table 3

Empirical U-O $\mathrm{O}_{\mathrm{Ur}}$ atomic distances, calculated using selected $v_{1}\left(\mathrm{UO}_{2}\right)^{2+}$ symmetric stretching vibration bands. Values in bold correspond to most defined experimental bands; i.e. most reliable data. Reference distance values extracted from *KhosrawanSazedj [26] and ${ }^{* *}$ Locock and Burns [15].

\begin{tabular}{llll}
\hline Experiment & $v_{1}\left(\mathrm{UO}_{2}\right)^{2+}\left(\mathrm{cm}^{-1}\right)$ & $\mathrm{U}-\mathrm{O}_{\mathrm{Ur}}(\AA)$ & Reference distances \\
\hline $\mathrm{U}-1$ & 821 & 1.79 & $1.80 \AA \mathrm{U}(2)-\mathrm{O}(4)^{*}$ \\
& $\mathbf{8 1 5}$ & $\mathbf{1 . 8 0}$ & \\
$\mathrm{U}-2$ & 809 & 1.80 & \\
& 831 & 1.78 & - \\
& $\mathbf{8 2 5}$ & $\mathbf{1 . 7 9}$ & \\
$\mathrm{U}-3$ & 809 & 1.80 & \\
& 831 & 1.78 & $1.78 \AA \mathrm{U}(2)-\mathrm{O}(3)^{* *}$ \\
& $\mathbf{8 2 7}$ & $\mathbf{1 . 7 8}$ & \\
\hline & 806 & 1.80 & \\
\hline
\end{tabular}

first region defines the lattice modes and the second region, the $v_{2}$ $\left(\mathrm{UO}_{2}\right)^{2+}$ vibrations. Bands (at 96, 104, 126 and $142 \mathrm{~cm}^{-1}$ ) for $\mathrm{U}-2$ and $\left(81,99,113,125\right.$ and $\left.145 \mathrm{~cm}^{-1}\right)$ for $\mathrm{U}-3$ are attributed to the lattice modes. The most intense band at 96 and $99 \mathrm{~cm}^{-1}$ for U-2 and $\mathrm{U}-3$, respectively, could be ascribed to $\mathrm{CuO}$ vibrations. The bands observed at higher wavenumbers $(174,194,208,222,251$, 286 and $301 \mathrm{~cm}^{-1}$ ) for U-2 and $\left(196,221,253\right.$ and $\left.291 \mathrm{~cm}^{-1}\right)$ for $\mathrm{U}-3$ are attributed to the $v_{2}\left(\mathrm{UO}_{2}\right)^{2+}$ bending vibrations [20].

\section{vOH stretching vibrations of water molecules}

The spectral profiles of the samples $U-1$ and $U-3$ are broad and curve-resolved bands could not be evaluated. However, the bands for the barian metatorbernite sample, which is the focus of this study, are well distinguishable and the band component were resolved at $3040,3212,3360$ and $3476 \mathrm{~cm}^{-1}$. The Raman spectrum in the hydroxyl stretching region $\left(2600-3800 \mathrm{~cm}^{-1}\right)$ of U-2 is displayed in Fig. 7. These bands are in very good agreement with the bands assigned by Frost [18] to the $\mathrm{OH}$ stretching vibrations of

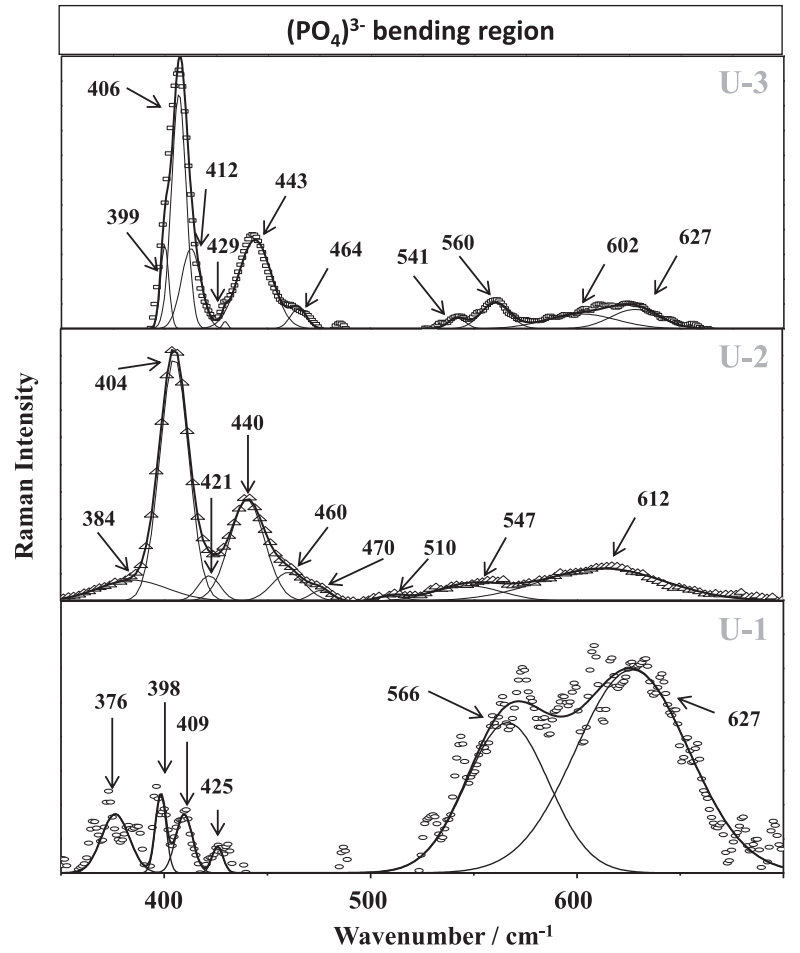

Fig. 5. Raman spectra of the $U-1, U-2$ and $U-3$ samples in the phosphate and uranyl bending region $\left(350-700 \mathrm{~cm}^{-1}\right)$

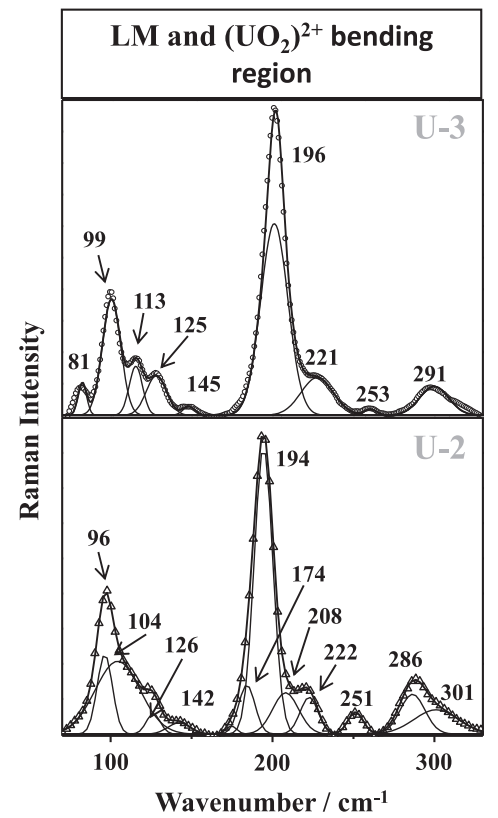

Fig. 6. Raman spectra of the U-2 and U-3 samples depicting the OM stretching and bending vibrations and the uranyl bending region $\left(70-350 \mathrm{~cm}^{-1}\right)$.

water molecules. The observation of four bands suggests that the water molecules in the structure could have different hydrogenbond strength [35]. Finally, the additional and broadbands at 1420 and $1543 \mathrm{~cm}^{-1}$ for U-1, 1412 and $1536 \mathrm{~cm}^{-1}$ for U-2 and 1414 and $1514 \mathrm{~cm}^{-1}$ for U-3 are attributed to $v 2(\delta)$ bending vibrations (Table 2) and, following the assignations from Frost [20], the bands at $1635 \mathrm{~cm}^{-1}$ for U-1 and U-2 and $1630 \mathrm{~cm}^{-1}$ for U-3 are probably assigned to the $\mathrm{OH}$ deformation mode (Table 2 ). 


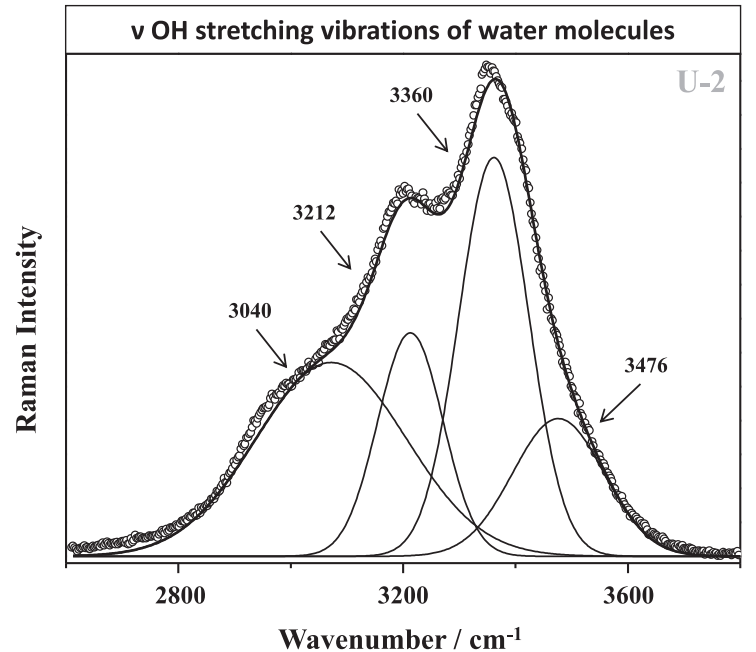

Fig. 7. Raman spectrum of the $\mathrm{U}-2$ sample showing the $\mathrm{OH}$ stretching region $\left(2600-3800 \mathrm{~cm}^{-1}\right)$.

\section{Implications for environmental science}

Uranyl phosphates play an important role in the reactive path followed by uranium in surface environments (from oxidative dissolution in primary phases to precipitation in low-solubility solids) mainly by limiting U-concentrations in both surface and groundwaters. In most cases, composition variations between close members of the autunite group minerals concern only a divalent cation - a misleadingly small difference with important consequences for both structure and aqueous reactivity. However, these are not phases occurring exclusively with perfectly stoichiometric compositions, since divalent cations may substitute for each other within the interlayer of autunite-type structures. Thus, realistic geochemical models regarding the aqueous mobility of $U(\mathrm{VI})$, especially in its final stages, should not only include pure members of the autunite-group, but also consider the incorporation of impurities, and the corresponding implications for uranyl phosphate solubility.

\section{Conclusions}

Raman spectroscopy has been used to characterize synthetic uranyl phosphate crystals of metatorbernite, metauranocircite and barian metatorbernite. This technique has proven most useful for the characterization of these phases due to the scarce amount of sample recovered from the gel experiments. The different regions in the Raman spectra were studied. The spectra of metauranocircite (U-1; Ba-bearing phase) are broad and show fluorescence, whereas those of metatorbernite (U-3; Cu-bearing phase) and the barian metatorbernite (U-2; $\mathrm{Ba}-\mathrm{Cu}$-bearing phase) are better defined. This is related to the quenching effect of cooper in the fluorescence. The stretching and bending modes of phosphate and uranyl groups were identified. Two phosphate symmetric stretching modes are observed, which means that two nonequivalent phosphate units are present in these minerals. U-O bond lengths were calculated with an empirical relation from Bartlett and Cooney's for the wavenumbers of the $v_{1}\left(\mathrm{UO}_{2}\right)^{2+}$ and the values are in agreement with those obtained from the published single crystal structure analyses of metatorbernite and uranocircite.

\section{Acknowledgements}

The authors acknowledge the financial support provided by both, the Ministerio de Ciencia e Innovación, Spain (Project CGL2010-20134-C02-01) and the Department of Geology of the University of Lisbon. This research project was also included in the cooperative actions "Acciones Integradas Luso-Españolas 2010", in partnership with the Department of Crystallography and Mineralogy of the University Complutense of Madrid jointly funded by the CRUP, Portugal, and the Ministerio de Ciencia e Innovación, Spain (reference AIB2010PT-00282). André Jorge Pinto acknowledges the support obtained from the post-doctoral scholarship, funded by the FCT ("Fundação para a Ciência e a Tecnologia", reference SFRH/BPD/65314/2009). We thank the Microscopy Centre of the Complutense University for technical assistance and support. We are also grateful to Laura Tormo and Alberto Jorge García (Madrid, Spain) for enabling Raman measurements at the MNCN, CSIC.

\section{References}

[1] R.C. Ewing, Elements 2 (2006) 331-334.

[2] R. Vochten, P. Piret, A. Bull. Mineral. 104 (1981) 457-467.

[3] E.S. Ilton, J.M. Zachara, D.A. Moore, J.P. Mckinley, A.D. Eckberg, C.L. Cahill, A.R Felmy, Environ. Sci. Technol. 44 (2010) 7521-7526.

[4] P.L. Airey, M. Ivanovich, Chem. Geol. 55 (1986) 203-213.

[5] C.C. Fuller, J.R. Bargar, J.A. Davis, J. Piana, Environ. Sci. Technol. 36 (2002) 158 165.

[6] J.L. Jerden, A.K. Sinha, Appl. Geochem. 18 (2003) 823-843.

[7] A.J. Pinto, M.A. Goncalves, C. Prazeres, J.M. Astilleros, M.J. Batista, Chem. Geol 312 (2012) 18-26.

[8] P.C. Burns, M.L. Miller, R.C. Ewing, Can. Mineral. 34 (1996) 845-880.

[9] P.C. Burns, Rev. Mineral. 38 (1999) 23-90.

[10] H.K. Henisch, J.M. García-Ruiz, J. Cryst. Growth 75 (1986) 203-211.

[11] H.K. Henisch, Crystals in Gels and Liesegang Rings. In Vitro Veritas, Cambridge University Press, New York, 1988.

[12] N. Sánchez-Pastor, N.C.M. Pina, L. Fernández-Díaz, Chem. Geol. 255 (2006) 266-277.

[13] N. Sánchez-Pastor, A.M. Gigler, J.A. Cruz, S-H. Park, G. Jordan, L. Ferná

ndez-Díaz, Cryst. Growth Des. 11 (2011) 3081-3089.

[14] A. Putnis, M. Prieto, L. Fernández-Díaz, Geol. Mag. 132 (1995) 1-13.

[15] A.J. Locock, P.C. Burns, Can. Mineral. 41 (2003) 91-101.

[16] M. Ross, H.T. Evans Jr., Am. Mineral. 49 (1964) 1578-1602.

[17] O.V. Yakubovich, I.M. Steele, D. Atencio, L.A. Menezes, N.V. Chukanov, Crystallogr. Rep. 53 (2008) 764-770.

[18] R.L. Frost, Spectrochim. Acta, Part A 60 (2004) 1469-1480.

[19] R.L. Frost, J. Cejka Jr., M. Weier, Spectrochim. Acta, Part A 65 (2006) 797-801.

[20] R.L. Frost, J. Cejka, G.A. Ayoko, M. Weier, Spectrochim. Acta, Part A 66 (2007) 979-984.

[21] J. Cejka Jr., A. Muck, J. Cejka, Phys. Chem. Miner. 11 (1984) 172-177.

[22] M. Wojdyr, J. Appl. Cryst. 43 (2010) 1126-1128.

[23] A.F. Hallimond, Mineral. Mag. 19 (1920) 43-47.

[24] K. Walenta, Jahresh. Geol. Landesamtes Baden-Wuerttemberg 6 (1963) 113 128.

[25] J.G. Fairchild, Am. Mineral. 14 (1929) 265-275.

[26] F. Khosrawan-Sazedj, Miner. Petrol. 29 (1982) 193-204.

[27] J.W. Anthony, R.A. Bideaux, K.W. Bladh, M.C. Nichols, Handbook of Mineralogy, vol. IV, Arsenates, Phosphates, Vanadates-Mineral Data Publishing, Tucson, Arizona, USA, 2000.

[28] A.J. Locock, P.C. Burns, T.M. Flynn, Can. Mineral. 43 (2005) 721-733.

[29] R. Vochten, L. van Haverbeke, K. van Springel, Mineral. Mag. 56 (1992) 367372 .

[30] Y. Suzuki, T. Sato, H. Isobe, T. Kogure, T. Murakami, Am. Mineral. 90 (2005) 1308-1314.

[31] G. Penel, G. Leroy, C. Rey, E. Bres, Calcified Tissue Int. 63 (1998) 475-481.

[32] Y.-H. Chen, E. Huang, S.-C. Yu, Solid State Commun. 149 (2009) 2050-2052.

[33] N. Sánchez-Pastor, A.M. Gigler, G. Jordan, W.W. Schmahl, L. Fernández-Díaz Spectrosc. Lett. 44 (2011) 500-504.

[34] J.R. Bartlett, R.P. Cooney, J. Mol. Struct. 193 (1989) 295-300.

[35] R.L. Frost, S.J. Palmer, J. Raman Spectrosc. 42 (2011) 1589-1595. 